\title{
Flexible antibodies with nonprotein hinges
}

\author{
By Daniel J. Capon ${ }^{* 1, \dagger}$ Naoki Kaneko, ${ }^{* 2}$ Takayuki Yoshimori, ${ }^{* 2}$ Takashi Shimada, ${ }^{* 2}$ \\ Florian M. Wurm, ${ }^{* 3}$ Peter K. Hwang,${ }^{* 4}$ Xiaohe Tong,${ }^{* 5}$ Staci A. AdAms, ${ }^{* 1}$ \\ Graham Simmons, ${ }^{* 1}$ Taka-Aki SATO ${ }^{* 2}$ and Koichi TANAKA ${ }^{* 2}$
}

(Contributed by Koichi TANAKA, M.J.A.)

\begin{abstract}
There is a significant need for antibodies that can bind targets with greater affinity. Here we describe a novel strategy employing chemical semisynthesis to produce symmetroadhesins: antibody-like molecules having nonprotein hinge regions that are more flexible and extendible and are capable of two-handed binding. Native chemical ligation was carried out under mild, non-denaturing conditions to join a ligand binding domain (A $\beta$ peptide) to an IgG1 Fc dimer via discrete oxyethylene oligomers of various lengths. Two-handed $\mathrm{A} \beta-\mathrm{Fc}$ fusion proteins were obtained in quantitative yield and shown by surface plasmon resonance to bind an anti- $\mathrm{A} \beta$ antibody with a $\mathrm{K}_{\mathrm{D}}$ at least two orders of magnitude greater than the cognate $\mathrm{A} \beta$ peptide. MALDITOF MS analysis confirmed the protein/nonprotein/protein structure of the two-handed molecules, demonstrating its power to characterize complex protein-nonprotein hybrids by virtue of desorption/ionization mediated by peptide sequences contained therein. We anticipate many applications for symmetroadhesins that combine the target specificity of antibodies with the novel physical, chemical and biological properties of nonprotein hinges.
\end{abstract}

Keywords: antibody, blood, native chemical ligation, $\mathrm{A} \beta$ peptide, PEG, MALDI-TOF MS

\section{Introduction}

The essence of the antibody molecule is its Yshape. By 1940, Pauling ${ }^{1)}$ had envisioned that antibodies have three regions and correctly predicted that the middle part has the same configuration as normal $\gamma$-globulin while the two ends have variable configurations that are complementary to the surface of the antigen. Porter ${ }^{2)}$ proved in 1958 that $\gamma$ globulin is formed from three globular sections, demonstrating that they could be split apart by papain. The sequence of one of these parts $(\mathrm{Fc})$ was shown to be essentially conserved in all $\gamma$-globulins, while the other two parts (Fab) varied considerably in sequence from molecule to molecule. By 1969, Edelman and colleagues ${ }^{3)}$ presented a complete

*1 Blood Systems Research Institute, San Francisco, U.S.A.

*2 Koichi Tanaka Laboratory of Advanced Science and Technology, Kyoto, Japan.

*3 Ecole Polytechnique Fédérale de Lausanne, 1015 Lausanne, Switzerland.

*4 University of California, San Francisco, California, U.S.A.

*5 CPC Scientific, Sunnyvale, California, U.S.A.

$\dagger$ Correspondence should be addressed: Daniel J. Capon, Blood Systems Research Institute, 270 Masonic Avenue, San Francisco, CA 94118, U.S.A. (e-mail: dcapon@alum.mit.edu). description of the connections between the Fab and Fc regions. Papain cleavage occurs within the two heavy chains releasing the Fab arms, each a light chain attached to the N-terminal portion of a heavy chain by a disulfide, from the $\mathrm{Fc}$ fragment, a disulfide-linked dimer of the C-terminal half of the heavy chains. All of the cysteines participating in these interchain disulfides bonds are clustered at the center of the heavy chain, giving the $\gamma$-globulins their Y-shape.

A more dynamic picture of $\gamma$-globulin structure has emerged from electron microscopy of antibodyantigen complexes. ${ }^{4), 5}$ ) In the presence of divalent haptens, antibodies form cyclic dimers, trimers, tetramers, pentamers and larger structures. Although the Fab and Fc parts have the appearance of rigid rods, the angle between them varies from zero to $180^{\circ}$, allowing them to bridge antigens at distances up to $120 \AA$. The antibody behaves as if all three parts were joined by a "hinge", the name now used for the heavy chain region containing the interchain disulfides. Despite its small size, just ten amino acids in IgG1, the hinge displays considerable variation in its configuration. The one available crystal structure of a human IgG1 with a full-length hinge ${ }^{6)}$ reveals 
extreme asymmetry in the placement of the Fab arms, reflecting differences in their distance and rotational displacement from the Fc. Although the hinges on adjacent heavy chains are separated by no more than $18 \AA$, the Fab arms diverge at a $148^{\circ}$ angle along their major axes and are rotated by $158^{\circ}$ along their depth axes.

Beginning in 1989, Capon and his Genentech collaborators reported that the Fab arms of IgG could be replaced with a variety of other proteins ${ }^{7)-14}$ including the extracellular domains of CD4, Lselectin, and tumor necrosis factor (TNF) receptor. These Y-shaped antibody-like molecules (called immunoadhesins or Fc fusion proteins) are cleaved by papain, like antibodies, into three fragments and have many of the biological properties of IgG including a long plasma half-life, Fc receptor and complement binding, and the ability to cross the placenta. All were shown to have therapeutic potential: CD4 immunoadhesin prevented HIV-1 infection in the chimpanzee, L-selectin immunoadhesin blocked neutrophil influx in mice, and TNF receptor immunoadhesin protected mice against lethal endotoxic shock. Their prolonged half-life in the blood ${ }^{7)}$ has proven particularly valuable, leading to the approval of five therapeutic drugs: $\left.{ }^{15}\right)$ etanercept (TNF receptor), abatercept (CTLA-4), alefacept (LFA-3), rilonbacept (IL-1 receptor), and romiplostim (thrombopoietin analog).

Such therapeutic antibodies are directed against targets that are multimeric proteins, suggesting they could be improved if both arms could grasp a particular target molecule. Unfortunately, this task is not straightforward as the hinge normally points the Fab arms away from each other. Outwardly pointing arms may have evolved to grasp large disease targets such as a bacteria, however inwardly pointing arms would be more suitable for grasping smaller targets such as proteins (e.g., TNF). The latter would likely require that the hinge is not only flexible, but extendible to a distance of at least several nanometers away from Fc, a combination of properties found in many types of polymer chains, but typically lacking in polypeptides. ${ }^{16)}$

An attractive solution would be to employ nonprotein chains to create antibody hinges that are both flexible and extendible. Here we describe significant progress towards these goals. We devised a chemical strategy based upon native chemical ligation $^{17)}$ that gives quantitative yields of $\mathrm{Fc}$ fusion proteins yet is compatible with the native, biologically active Fc molecule. Using this approach we fused a 15 amino acid stretch representing the immunodominant epitope of Alzheimer's A $\beta(1-42)$ fibrils ${ }^{18)-21)}$ and successfuly incorporated nonprotein chains between the $\mathrm{A} \beta$ and $\mathrm{Fc}$ moieties. MALDITOF MS, as pioneered by Tanaka and colleagues, ${ }^{22), 23)}$ was applied to unambiguously solve the structure of the nonprotein chain by virtue of the ionization and desorption of the adjacent protein regions. Our two-handed molecules bind targets with exceptional affinity, opening a promising avenue for the future development of improved antibody-based therapies.

\section{Materials and methods}

Human IgG1 Fc protein. The recombinant Fc protein (called Fc6) was expressed in Chinese hamster ovary $(\mathrm{CHO})$ cells and purified by Protein A affinity chromatography. A DNA expression vector was designed that directs the expression of a chimeric protein containing the human sonic hedgehog homolog ( $\mathrm{SHH}$ ) signal sequence fused to the human IgG1 heavy chain hinge region beginning at the ${ }^{226} \mathrm{CPPC}$ core hinge sequence (heavy chain residues are numbered according to the Eu format ${ }^{3)}$; residue ${ }^{226}$ Cys corresponds to Cys239 in Kabat \& $\mathrm{Wu}$ format). ${ }^{24)}$ The sequence of this vector (pCDNA3SHH-IgG1-Fc11) is described in Capon, D.J. (November 20, 2008) World Patent Cooperation Treaty, Publication No. WO/2008/140477. Following secretion and cleavage of the SHH signal sequence, the resulting mature Fc6 polypeptide has a predicted length of 222 residues. Production of Fc6 protein was executed by transient expression in CHO-DG44 cells, adapted to serum-free suspension culture. Transient transfections were done with polyethylenimine as transfection agent, complexed with DNA, under high density conditions as previously described. ${ }^{25)}$ Seed train cultures were maintained in TubeSpin ${ }^{\circledR}$ bioreactor 50 tubes and scaled up in volume to generate sufficient biomass for transfection. Transfections were carried out in cultures of 0.5 Liter to 1 Liter. Cultures at this scale were maintained in 2 Liter or 5 Liter Schott-bottles with a ventilated cap. The bottles were shaken at $180 \mathrm{rpm}$ in a Kühner incubator shaker with humidification and $\mathrm{CO}_{2}$ control at $5 \%$. The cell culture fluid was harvested after 10 days, centrifuged and sterilefiltered, prior to purification. The culture supernatant was applied to a column packed with rProtein A Fast Flow (GE Healthcare Bio-Sciences AB, Uppsala, Sweden) pre-equilibrated with Dulbecco's phosphate buffered saline without $\mathrm{Ca}$ or $\mathrm{Mg}$ salts 
Table 1. Synthetic peptides used in this study

\begin{tabular}{|c|c|c|c|c|}
\hline Peptide & No. & $\mathrm{Mr}(\mathrm{Da})$ & $\mathrm{MH}^{+}$ & Sequence \\
\hline A $\beta$-DKTHT & 1 & 2515.6 & 2516.68 & DAEFRHDSGYEVHHQ-DKTHT-thioester \\
\hline $\mathrm{A} \beta-\mathrm{PEG}_{12}-\mathrm{DKTHT}$ & 2 & 3115.6 & 3115.64 & DAEFRHDSGYEVHHQ- $P E G_{12}$-DKTHT-thioester \\
\hline $\mathrm{A} \beta-\mathrm{PEG}_{24}-\mathrm{DKTHT}$ & 3 & 3629.7 & 3629.67 & DAEFRHDSGYEVHHQ- $P E G_{2 / 4}$-DKTHT-thioester \\
\hline $\mathrm{A} \beta-\mathrm{PEG}_{36}-\mathrm{DKTHT}$ & 4 & 4158.2 & 4158.40 & DAEFRHDSGYEVHHQ- $P E G_{36}$-DKTHT-thioester \\
\hline DKTHT & 5 & 776.8 & 776.60 & Azidoacetyl-DKTHT-thioester \\
\hline pen- $\mathrm{A} \beta$ & 6 & 1921.0 & 1921.94 & pentynoyl-DAEFRHDSGYEVHHQ- $\mathrm{NH}_{2}$ \\
\hline $\mathrm{A} \beta$-pra & 7 & 1905.9 & 1906.56 & DAEFRHDSGYEVHHQ- propargylglycine- $\mathrm{NH}_{2}$ \\
\hline
\end{tabular}

Amino acid sequences are shown in boldface.

Thioester $=$ thiophenol (peptides 1, 4, 5); benzyl mercaptan (peptides 2, 3).

$\mathrm{Mr}$, relative molecular mass; $\mathrm{MH}^{+}$, monoisotypic mass value (observed).

(PBS) (UCSF Cell Culture Facility, San Francisco, CA). The column was washed extensively with PBS and the Fc6 protein eluted with $0.1 \mathrm{M}$ glycine buffer $\mathrm{pH}$ 2.7. Fractions were collected into tubes containing $0.05 \mathrm{v} / \mathrm{v} 1.0 \mathrm{M}$ Tris-HCL pH 9.0 (giving a final $\mathrm{pH}$ of 7.5), pooled, dialyzed against PBS, and stored at $4^{\circ} \mathrm{C}$ prior to use.

Peptides. All peptides used in this study (Table 1) were synthesized by an Fmoc/t-Butyl solid-phase strategy on a 2-chlorotrityl chloride resin preloaded with the Fmoc-Thr(tBu)-OH. Amino acid derivatives were obtained from CPC Scientific (Sunnyvale, CA), Fmoc-PEG $\mathrm{x}_{\mathrm{x}} \mathrm{OH}$ derivatives were purchased from Quanta BioDesign (Powell, OH), and 2-(1H-benzotriazole-1-yl)-1,1,3,3-tetramethylaminium hexafluorophosphate (HBTU), dichloromethane (DCM), trichloroacetic acid (TFA), N,N'diisopropylcarbodiimide (DIC), 1-hydroxybenzotriazole (HOBt), N,N'-diisopropylethylamine (DIEA) and triisopropylsilane (TIS) were purchased from Sigma (St. Louis, MO). The standard HBTU activation was employed for peptide elongation. Peptides 2-4 required the insertion of a Fmoc$\mathrm{PEG}_{\mathrm{x}} \mathrm{OH}(\mathrm{x}=12,24$ and 36 , respectively). As a final step in peptide elongation, the terminal $\alpha$-Fmoc (9-fluorenylmethoxycarbonyl) protecting group was converted to Boc (tert-butoxycarbonyl). The peptide resin was washed with DCM and cleaved with $1 \%$ TFA/DCM to yield the fully protected peptide with a free carboxylic acid on the C-terminus. The thioester of the peptides was formed by treating the crude protected peptide with DIC/HOBt/DIEA and either thiophenol (peptides 1, 2, 5) or benzyl mercaptan (peptides 3, 4) in DCM overnight. After concentration, the crude protected peptide thioester was precipitated by multiple triturations with cold ether followed by centrifugation. Deprotection was carried out by treatment of the crude protected product with 95:2.5:2.5 TFA/TIS/ $\mathrm{H}_{2} \mathrm{O}$ for 2 hours at room temperature. After precipitation with ice-cold ether the deprotected peptide thioester was purified by preparative $\mathrm{RP}-\mathrm{HPLC}$ in a $\mathrm{H}_{2} \mathrm{O}$-acetonitrile $(0.1 \%$ TFA $)$ system to afford the final product with 91-95\% purity and the desired MS.

Chemical semisynthesis of symmetroadhesins. 2-(N-morpholino)ethanesulfonic acid (MES) was purchased from Acros (Morris Plains, NJ), tris(2-carboxyethyl)phosphine (TCEP) was purchased from Pierce (Rockford, IL), and 4-mercaptophenylacetic acid (MPAA) was purchased from Sigma-Aldrich (St. Louis, MO). Reactions contained $50 \mathrm{mM}$ MES buffer $\mathrm{pH} 6.5,0.8 \mathrm{mM}$ TCEP, $10 \mathrm{mM}$ MPAA, $5 \mathrm{mg} / \mathrm{ml}$ of the peptide thioester, and $1 \mathrm{mg} / \mathrm{ml}$ of Fc6 protein. Following incubation for 15 hours at room temperature, reactions were adjusted to $\mathrm{pH} 7.0$ with $0.05 \mathrm{v} / \mathrm{v}$ of $1 \mathrm{M}$ Tris- $\mathrm{HCl} \mathrm{pH} 9.0$ and purified on HiTrap Protein A HP columns purchased from GE Healthcare (Piscataway, NJ). The reaction products were analyzed by SDS polyacrylamide gel electrophoresis (SDS-PAGE) under reducing conditions using NuPAGE ${ }^{\circledR}$ Novex Bis-Tris Midi Gels (10\%) purchased from Invitrogen (Carlsbad, CA). Proteins were visualized using Silver Stain Plus or Coomassie Brilliant Blue R-250 purchased from BioRad (Hercules, CA).

In-gel tryptic digestion of proteins. HPLCgrade acetonitrile $(\mathrm{ACN})$ and trifluoroacetic acid (TFA) were purchased from Wako Pure Chemical Industries (Osaka, Japan). Ammonium bicarbonate $\left(\mathrm{NH}_{4} \mathrm{HCO}_{3}\right)$, dithiotreitol (DTT) and iodoacetamide (IAA) were purchased from Nacalai Tesque (Kyoto, Japan). Sequence grade Trypsin was purchased from Promega (Madison, WI). The protein bands from the gel were excised and destained with $300 \mathrm{\mu l}$ of $50 \% \mathrm{v} / \mathrm{v}$ $\mathrm{ACN}$ in $50 \mathrm{mM} \mathrm{NH}_{4} \mathrm{HCO}_{3}$ at $4^{\circ} \mathrm{C}$ for $45 \mathrm{~min}$. The gel pieces were dehydrated in $150 \mu \mathrm{l}$ of $100 \% \mathrm{ACN}$ for 
10 min at room temperature following drying with a Speed $\operatorname{Vac}^{\circledR}$ for $30 \mathrm{~min}$. A volume of $100 \mu \mathrm{l}$ of $10 \mathrm{mM}$ DTT in $50 \mathrm{mM} \mathrm{NH}_{4} \mathrm{HCO}_{3}$ was added to the dried gels to reduce sulfide bond for 1 hour at $37^{\circ} \mathrm{C}$. After the solution was removed, the proteins were alkylated in $100 \mathrm{\mu l}$ of $55 \mathrm{mM}$ IAA in $50 \mathrm{mM} \mathrm{NH}_{4} \mathrm{HCO}_{3}$ for 1 hour at room temperature under the dark. Afterward the gel pieces were washed with $150 \mu \mathrm{l}$ of $50 \mathrm{mM}$ $\mathrm{NH}_{4} \mathrm{HCO}_{3}$ and then dehydrated in $150 \mu \mathrm{l}$ of $100 \%$ ACN. This step was repeated 2 times. The gel pieces were then dried in a vacuum centrifuge for $30 \mathrm{~min}$. The dried gels were rehydrated with $2 \mu \mathrm{l}$ of $50 \mathrm{ng} / \mu \mathrm{l}$ Trypsin in $50 \mathrm{mM} \mathrm{NH}_{4} \mathrm{HCO}_{3}$ and incubated for $5 \mathrm{~min}$ at room temperature. Then, $18 \mu$ l of ultrapure water was further added and the proteins were digested at $37^{\circ} \mathrm{C}$ overnight. After digestion, $40 \mu \mathrm{l}$ of $50 \% \mathrm{v} / \mathrm{v}$ ACN containing $0.1 \% \mathrm{v} / \mathrm{v}$ TFA was added to the digestion mixtures and the gel pieces were sonicated for $15 \mathrm{~min}$. The supernatant was collected into a new $0.5 \mathrm{ml}$ tubes.

MALDI-TOF MS analysis. MALDI mass spectra were obtained using AXIMA performance MALDI-TOF mass spectrometer (Shimadzu/ KRATOS, Manchester, UK) equipped with a 337 $\mathrm{nm}$ nitrogen laser in the positive ion reflectron mode and linear mode. $\alpha$-cyano-4-hydroxy-cinnamic acid (CHCA) and sinapinic acid (SA) were obtained from LaserBio Labs (Sophia-Antipolis Cedex, France). As the MALDI matrices, CHCA was used for trysindigested proteins and SA was used for SEC-separated proteins. The matrix solutions were prepared by dissolving $5 \mathrm{mg}$ of the matrix compounds in $0.5 \mathrm{ml}$ of $50 \% \mathrm{v} / \mathrm{v}$ ACN containing $0.1 \% \mathrm{v} / \mathrm{v}$ TFA. The sample solution $(0.5 \mu \mathrm{l})$ was mixed with an equivalent amount of the matrix solution on the target plate and then dried at room temperature for MALDITOF MS analysis. The $m / z$ values were calibrated with 2 pmol each of [Angiotensin $\mathrm{I}+\mathrm{H}^{+}$] $(\mathrm{m} / z$ 1296.7), [Angiotensin $\left.\mathrm{II}+\mathrm{H}^{+}\right] \quad(m / z \quad 1046.5)$, [[Glu1]-Fibrinopeptide $\left.\mathrm{B}+\mathrm{H}^{+}\right] \quad(m / z \quad 1570.7),[\mathrm{N}-$ acetyl-resin substrate tetradecapeptide $\left.\mathrm{I}+\mathrm{H}^{+}\right](\mathrm{m} / \mathrm{z}$ 1800.9), [ACTH fragment $1-17+\mathrm{H}^{+}$] $(m / z 2093.1)$ and [ACTH fragment $\left.18-39+\mathrm{H}^{+}\right](\mathrm{m} / z 2464.2)$, and 3 pmol of [ACTH fragment $\left.7-38+\mathrm{H}^{+}\right](m / z 3656.9)$, $7.5 \mathrm{pmol}$ of [Bovine serum albumin $\left.+\mathrm{H}^{+}\right] \quad(\mathrm{m} / \mathrm{z}$ 66430.09 (average)) and [Aldolase $+\mathrm{H}^{+}$] $(\mathrm{m} / \mathrm{z}$ 39212.28 (average)) as external standard.

Size exclusion chromatography (SEC). SEC was carried out with similar results using a Prominence HPLC System (Shimadzu Corp, Kyoto, Japan) or an AKTA Avant FPLC System (GE Healthcare, Piscataway, NJ). TSKgel columns were purchased from TOSOH Bioscience (Tokyo, Japan). Mobile phase, flow rate, column temperature, and detection wavelength used were $50 \mathrm{mM}$ sodium phosphate $\mathrm{pH} 7.4$ and $300 \mathrm{mM} \mathrm{NaCl}, 0.35 \mathrm{~mL} / \mathrm{min}$, $25^{\circ} \mathrm{C}$, and $214 / 280 \mathrm{~nm}$, respectively. All four $\mathrm{A} \beta$ PEGx-Fc symmetroadhesins $(\mathrm{x}=0,12,24$, and 36$)$ were analysed side-by-side in each experiment. To analyse the efficiency of synthesis of the two-handed molecules, $5 \mu \mathrm{L}$ of each Protein A purified reaction product was applied to a TSKgel SuperSW3000 [ $4.6 \mathrm{~mm}$ I.D. $\times 30 \mathrm{~cm} \mathrm{~L}]$ column. The ratio of the molecular species was calculated from the area under each peak. To confirm the subunit structures of the two-handed and one-handed molecules by SDSPAGE, the Protein A purified reaction products were first concentrated 10-fold using an $0.5 \mathrm{ml}$ Amicon Ultracel-3K centrifugal filters (Millipore, Cork, IR); $50 \mu \mathrm{l}$ of each concentrate was then applied to four TSKgel columns coupled in series $(2$ G2000SW $\mathrm{XL}$ and 2 G3000SW $\mathrm{XL}_{\mathrm{X}}[7.8 \mathrm{~mm}$ I.D. $\times 30 \mathrm{~cm} \mathrm{~L}]$ columns). Fractions were then analyzed using NuPAGE ${ }^{\circledR}$ Novex Bis-Tris Midi Gels (4-12\%) under reducing conditions. For the determination of the molecular weight of the two major species observed by SEC, $50 \mu \mathrm{L}$ of each Protein A purified reaction was applied to TSKgel G3000SW $\mathrm{XL} \quad[7.8 \mathrm{~mm} \quad$ I.D. $\times 30 \mathrm{~cm} \mathrm{~L}]$ column. Peak fractions were analysed by MALDITOF MS analysis in the linear mode.

Surface plasmon resonance (SPR). SPR studies were carried out using a Biacore T100 instrument (Biacore AB, Uppsala, Sweden). The ligand, biotin-labeled 6E10 monoclonal antibody (Covance, Princeton, NJ), was immobilized at a concentration of $10 \mathrm{mg} / \mathrm{ml}$ in PBS onto a CAP sensor chip, Series S, using a Biotin CAPture Kit (GE Healthcare, Piscataway, NJ). The sensor chip was loaded with the streptavidin capture reageant and regenerated according to the manufacturer's instruction, including an additional regeneration step with $0.25 \mathrm{M} \mathrm{NaOH}$ in $30 \%$ acetonitrile. Binding of the $\mathrm{A} \beta$ symmetroadhesins and $\mathrm{A} \beta$ peptides was carried out at $25^{\circ} \mathrm{C}$ in $10 \mathrm{mM}$ Hepes buffer $\mathrm{pH} 7.4,150 \mathrm{mM} \mathrm{NaCl}$, $3 \mathrm{mM}$ EDTA, and $0.005 \%$ Tween-20. Data was evaluated using Biacore T100 Evaluation Software, version 2.0.3.

\section{Results}

Quantitative synthesis of symmetroadhesins. Our strategy for chemical semisynthesis of $\mathrm{A} \beta$ symmetroadhesins is summarized in Fig. 1. Native chemical ligation was carried out with recombinant Fc protein (Fc6) engineered to have cysteine residues 

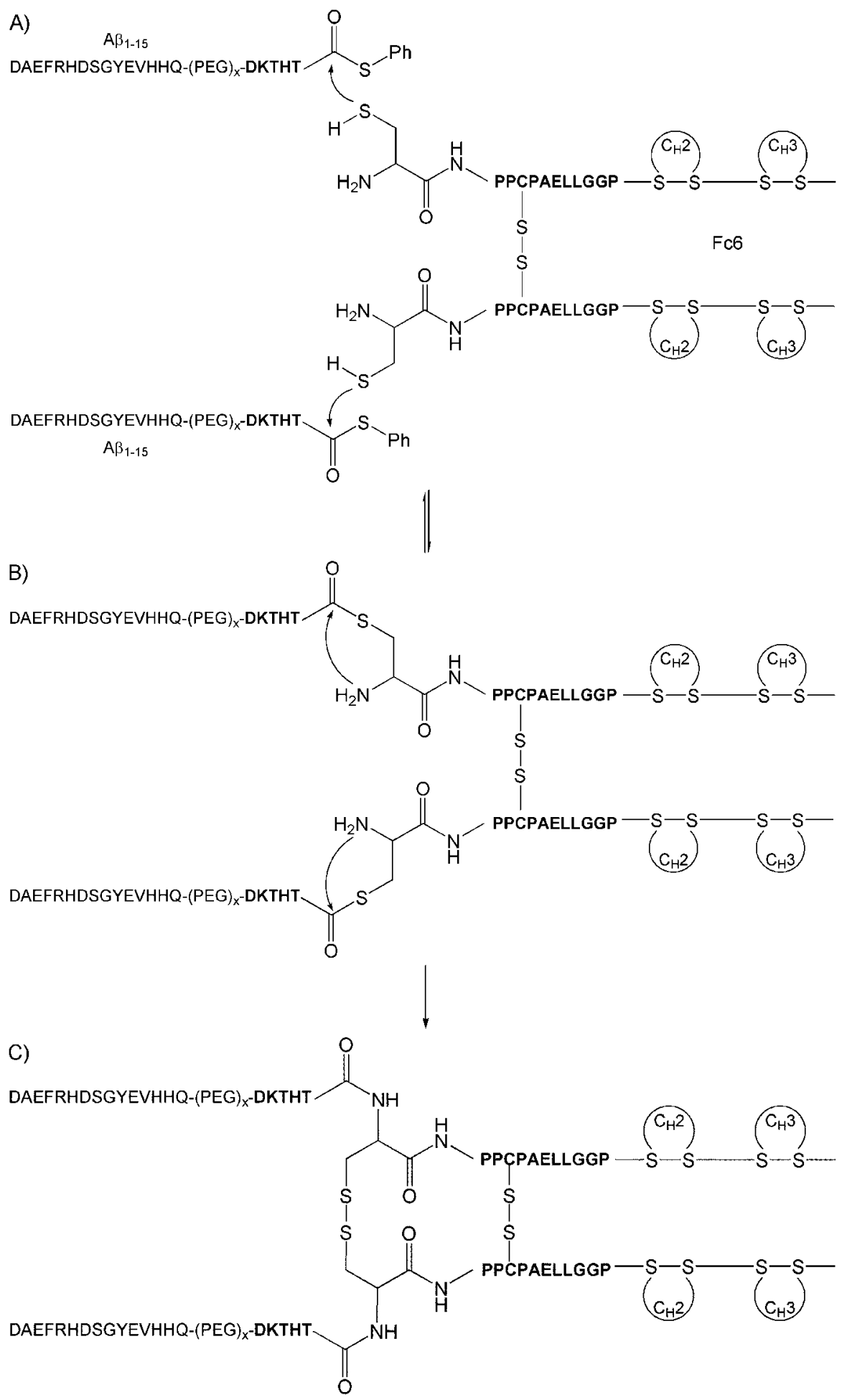

Fig. 1. Chemical semisynthesis of $A \beta-P E G_{x}-F c$ fusion proteins, showing the following steps: (A) reversible formation of the S-acyl intermediate by transthioesterification; (B) the S-acyl intermediate undergoing spontaneous S- to N-acyl migration; (C) irreversible formation of the peptide bond via a five-membered ring intermediate. The sequences of the IgG1 hinge region are shown in boldface. 
at both N-termini. We developed mildly reducing, non-denaturing conditions that favor a stable Fc dimer, yet maintain the sulfhydryl groups of the Nterminal cysteines in a reduced state, allowing the Fc6 molecule to readily react with $\mathrm{C}$-terminal thioesters. Nucleophilic acyl substitution involving both Nterminal sulfhydryls of the Fc6 molecule as nucleophiles (Fig. 1A) leads to thioester-linked intermediates with two $\mathrm{A} \beta$ thioesters (Fig. 1B). Subsequent nucleophilic attack by both of the Fc6 N-terminal amino groups followed by intramolecular rearrangement results in irreversible peptide bond formation between Fc6 and two A $\beta$ peptides (Fig. 1C).

To obtain the Fc6 protein, we employed a recombinant DNA construct that placed a signal sequence adjacent to a cysteine residue normally found in the hinge region. The IgG1 hinge region contains three cysteine residues: ${ }^{220} \mathrm{Cys}$ in the upper hinge region (CDKTHT) which usually participates in the disulfide bond between the heavy and light chains, and ${ }^{226} \mathrm{Cys}$ and ${ }^{229} \mathrm{Cys}$ in the core hinge region (CPPC) which are sometimes present in the interchain disulfide bonds between two heavy chains. We selected ${ }^{226}$ Cys over ${ }^{220}$ Cys as the N-terminus for our Fc molecules, since molecules with ${ }^{220} \mathrm{Cys}$ at their N-terminus (Fc3) were less easily reduced as judged by thiol-sepharose binding experiments (not shown). In addition, ${ }^{226}$ Cys was selected over ${ }^{229}$ Cys as the Nterminus since it has a greater potential to stabilize symmetroadhesins, as suggested by crystallographic structures of human IgG1 showing the ${ }^{226} \mathrm{Cys}$ residues clearly covalently bonded while the ${ }^{229} \mathrm{Cys}$ residues are visibly separated. ${ }^{17)}$

The signal sequence of the sonic hedgehog homolog $(\mathrm{SHH})$ was chosen for the secretion and processing of the $\mathrm{Fc}$ protein since its own mature polypeptide has an N-terminal cysteine. The pCDNA3-SHH-IgG1-Fc11 construct efficiently directed the synthesis of the Fc6 protein following transient transfection of Chinese Hamster Ovary (CHO) cells. Figure 2 shows that the Fc6 product obtained by affinity purification of the transfected CHO cell supernatants has an apparent molecular weight of 27,000 daltons on SDS-PAGE under reducing conditions (lane 1 ). The Fc6 protein was well expressed in transient transfections reaching levels exceeding $0.8 \mathrm{~g} / \mathrm{L}$ and was found to quantitatively bind and elute from Protein A affinity resins.

The ability of Fc6 to react with five different Cterminal thioesters (listed in Table 1) was investigated. All five thioesters contain a portion of the upper hinge region (DKTHT) at their C-terminus.

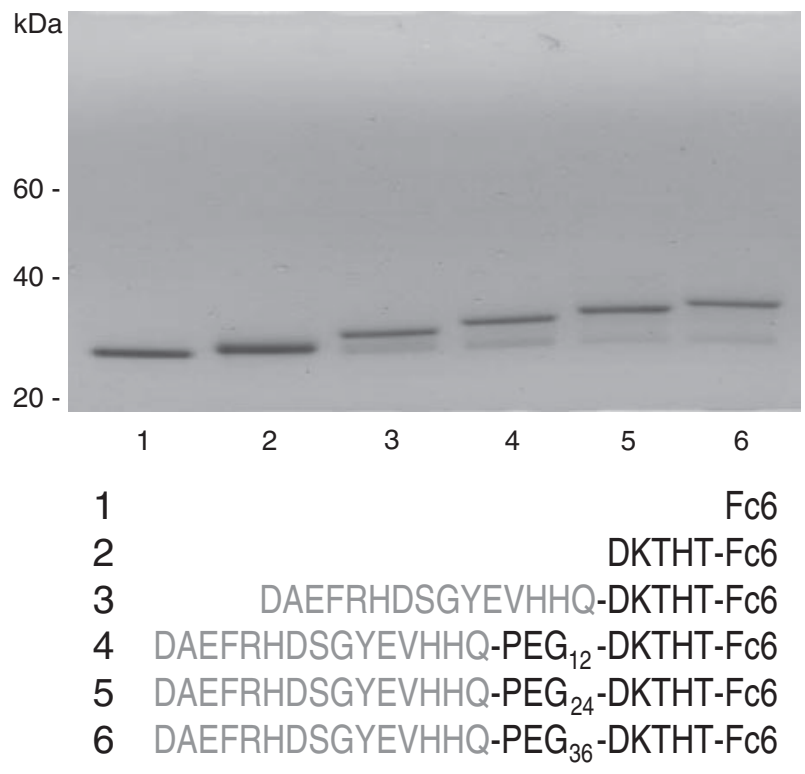

Fig. 2. SDS-PAGE analysis of the unreacted Fc6 protein and chemically synthesized fusion proteins as follows: (1) Fc6; (2) DKTHT-Fc6; (3) A $\beta$-Fc; (4) $\mathrm{A}_{\beta}-\mathrm{PEG}_{12}-\mathrm{Fc}$; (5) $\mathrm{A} \beta-\mathrm{PEG}_{24}-\mathrm{Fc}$; (6) $\mathrm{A} \beta-\mathrm{PEG}_{36}-\mathrm{Fc}$.

Four of the five thioesters also contained a 15 amino acid sequence from the human $\mathrm{A} \beta$ protein (DAEFRHDSGYEVHHQ) joined at its C-terminus to the N-terminus of the upper hinge region. In addition, three of the $\mathrm{A} \beta$ containing thioesters incorporated a nonpeptide chain between the $\mathrm{A} \beta$ and upper hinge sequences. The nonpeptide portion in these peptides consisted of discrete oxyethylene oligomers (PEG) of chain lengths 12, 24, or 36 .

Figure 2 shows that Fc6 reacted quantitatively with all five thioesters, yielding a ladder of products of increasing size on SDS-PAGE under reducing conditions (lanes $2-6$ ). The addition of the $\mathrm{PEG}_{12}$ oligomer gave a size increase on SDS-PAGE similar to the 15 amino acid residue $\mathrm{A} \beta$ sequence (compare Fig. 2, lanes 2-4). This suggests that a single amino acid residue and a single oxyethylene monomer unit make similar contributions to contour length, consistent with the comparable lengths of their trans conformations (approximately 3.5 to $4 \AA$ ). ${ }^{16}$ ) The addition of $\mathrm{PEG}_{24}$ and $\mathrm{PEG}_{36}$ gave further size increases over $\mathrm{PEG}_{12}$ that were consistent (compare Fig. 2, lanes 3-6).

Since we produced Fc6 as a native, folded protein by secretion in mammalian cells, it was critically important to avoid the use of chaotropic agents and strong reducing conditions typically employed in other native chemical ligation studies. ${ }^{17}$ ) 
Nevertheless, mild reducing conditions were essential as the Fc6 protein was found to be essentially unreactive with thioesters otherwise (not shown). Quantitative yields of symmetroadhesins (>90\%) were readily obtained as seen in Fig. 2 by combining a non-thiol reducing agent such as tris(2-carboxyethyl)phosphine with a thiol reducing agent such 4mercaptophenylacetic acid. ${ }^{26)}$

Symmetroadhesin primary structure analysis. To confirm the exact nature of the chemical linkage between the $\mathrm{A} \beta$ sequence and Fc6, we analyzed the monomer structures of the four $\mathrm{A} \beta$ symmetroadhesins by mass spectrometry. The $\mathrm{A} \beta$ $\mathrm{Fc}, \mathrm{A} \beta-\mathrm{PEG}_{12}-\mathrm{Fc}, \mathrm{A} \beta-\mathrm{PEG}_{24}-\mathrm{Fc}$ and $\mathrm{A} \beta-\mathrm{PEG}_{36}-\mathrm{Fc}$ symmetroadhesin reaction products were purified by SDS-PAGE and characterized using in-gel tryptic digestion. The peaks detected by MALDI-TOF MS were fit to the theoretical peptides predicted for each symmetroadhesin, yielding a sequence coverage between 78.9-81.8\% (Fig. 3A-D). This sequence coverage was sufficient to uniquely identify each of the symmetroadhesins. We focused our analysis on two sequences: the $\mathrm{A} \beta-\mathrm{PEG}_{\mathrm{x}}-\mathrm{DK}$ fragment which should be different in all four symmetroadhesins, and the THT-Fc6 fragment which represents the chemical ligation site and should be identical in all four symmetroadhesins (Fig. 3E). The theoretical $m / z$ values for these five predicted sequences are shown in Fig. 3F. The observed MS spectra revealed peaks at $m / z$ values that are in excellent agreement with all four unique fragments $(\mathrm{A} \beta-\mathrm{DK}, \mathrm{A} \beta$ $\mathrm{PEG}_{12}$-DK, $\left.\mathrm{A} \beta-\mathrm{PEG}_{24}-\mathrm{DK}, \mathrm{A} \beta-\mathrm{PEG}_{36}-\mathrm{DK}\right)$ as well as the common ligation site fragment (THTCPPCPAPELLGGPSVFLFPPKPK).

Symmetroadhesin subunit molecular structure. The $\mathrm{A} \beta$ symmetroadhesin reaction products were expected to have a dimeric structure similar to the parent Fc6 molecule. In addition, given the small amount $(<10 \%)$ of apparently unreacted material Fc6 observed in all four reactions (Fig. 2, lanes 3-6), each reaction product could be a mixture of homodimers having two A $\beta$ "hands", heterodimers having one A $\beta$ "hand", and unreacted Fc6 homodimers. Accordingly, size-exclusion chromatography (SEC) was used to investigate the subunit molecular structure of the four $\mathrm{A} \beta$ symmetroadhesins. The $\mathrm{A} \beta$ $\mathrm{Fc}, \mathrm{A} \beta-\mathrm{PEG}_{12}-\mathrm{Fc}, \quad \mathrm{A} \beta-\mathrm{PEG}_{24}-\mathrm{Fc}$ and $\mathrm{A} \beta-\mathrm{PEG}_{36^{-}}$ $\mathrm{Fc}$ reaction products were purified from unreacted thioester by Protein A affinity chromatography and then analyzed by SEC under native, non-reducing conditions $(50 \mathrm{mM}$ sodium phosphate $\mathrm{pH} 7.4$, $300 \mathrm{mM} \mathrm{NaCl}$ ). Figure 4 shows that all four of the
Table 2. $\mathrm{A} \beta-\mathrm{PEG}_{\mathrm{x}}-\mathrm{Fc}$ symmetroadhesin product ratios determined by size exclusion chromatograpy (SEC)

\begin{tabular}{ccccc}
\hline Reaction & Two-handed & One-handed & No A $\beta$ hand & HMW \\
\hline $\mathrm{A} \beta-\mathrm{Fc}$ & $72.7 \%$ & $24.6 \%$ & $2.5 \%$ & $0.2 \%$ \\
$\mathrm{~A} \beta-\mathrm{PEG}_{12}-\mathrm{Fc}$ & $66.1 \%$ & $29.5 \%$ & $4.4 \%$ & $\mathrm{ND}$ \\
$\mathrm{A} \beta-\mathrm{PEG}_{24}-\mathrm{Fc}$ & $74.6 \%$ & $19.8 \%$ & $2.8 \%$ & $2.8 \%$ \\
$\mathrm{~A} \beta-\mathrm{PEG}_{36}-\mathrm{Fc}$ & $70.9 \%$ & $24.1 \%$ & $2.6 \%$ & $2.4 \%$ \\
\hline
\end{tabular}

The product ratios for each the four (4) reactions shown in Fig. 3A-D were calculated directly from the area of each peak. HMW, higher molecular weight species; ND, not detected.

symmetroadhesin reaction products exhibited two main peaks. The sizes of these two main peaks increased in the order $\mathrm{A} \beta-\mathrm{Fc}<\mathrm{A} \beta-\mathrm{PEG}_{12}-\mathrm{Fc}<\mathrm{A} \beta$ $\mathrm{PEG}_{24}-\mathrm{Fc}<\mathrm{A} \beta-\mathrm{PEG}_{36}-\mathrm{Fc}$ (Fig. $\left.4 \mathrm{~A}-\mathrm{D}\right)$. Furthermore, the size separation between the two main peaks that was observed for a given symmetroadhesin reaction product increased in the same relative order. In addition, all four symmetroadhesin reaction products displayed a smaller minor peak at $24.4 \mathrm{~min}$ having the size expected for unreacted Fc6 dimer. Together, these observations suggested that the larger and smaller major peaks represent the predicted "two-handed" and "one-handed" symmetroadhesins, respectively. As summarized in Table 2, the two-handed symmetroadhesin candidate was the major product observed in each of the four reactions (66-74\%). Finally, three of the reaction products also exhibited a minor higher molecular weight (HMW) peak (Fig. 4A, C, D). As for the two main peaks, the size of this peak increased with the length of the oxyethylene oligomer.

To confirm the predicted subunit structures of the two-handed and one-handed symmetroadhesins, preparative SEC was carried out under the native, non-reducing conditions (Fig. 5A) and the resulting column fractions were analyzed by SDS-PAGE under reducing conditions (Fig. 5B-E). In each of the four symmetroadhesin reactions, the candidate peak for the two-handed symmetroadhesin consisted almost exclusively of the expected $\mathrm{A} \beta-\mathrm{PEG}_{\mathrm{x}}-\mathrm{Fc}$ product $(\mathrm{x}=0,12,24,36)$, confirming its homodimeric structure. Similarly, the candidate peak for the onehanded symmetroadhesin consisted of a 1:1 ratio of the expected $\mathrm{A} \beta-\mathrm{PEG}_{\mathrm{x}}-\mathrm{Fc}$ product and apparently unreacted Fc6, confirming its heterodimeric structure.

To establish the exact molecular relationship between the two-handed and one-handed symmetroadhesins, the two main peaks observed on analytical size-exclusion chromatograms were analyzed 
A) $A \beta-F c$

B) $A \beta-P E G_{12}-F c$

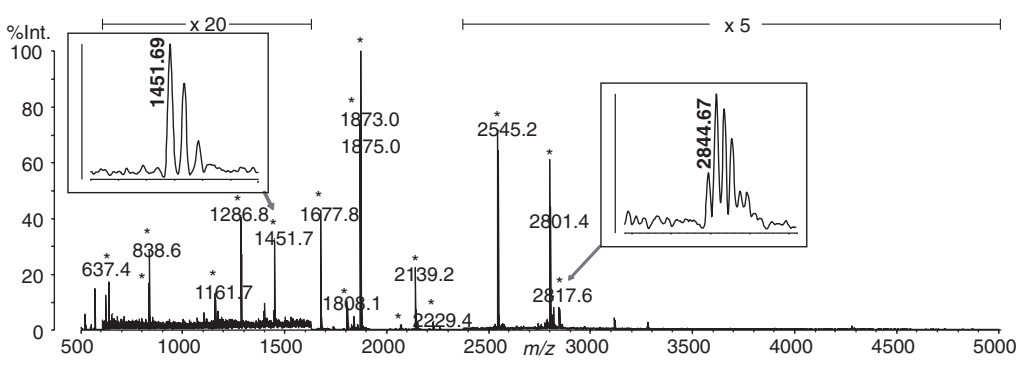

C) $\mathrm{A} \beta-\mathrm{PEG}_{24}-\mathrm{Fc}$

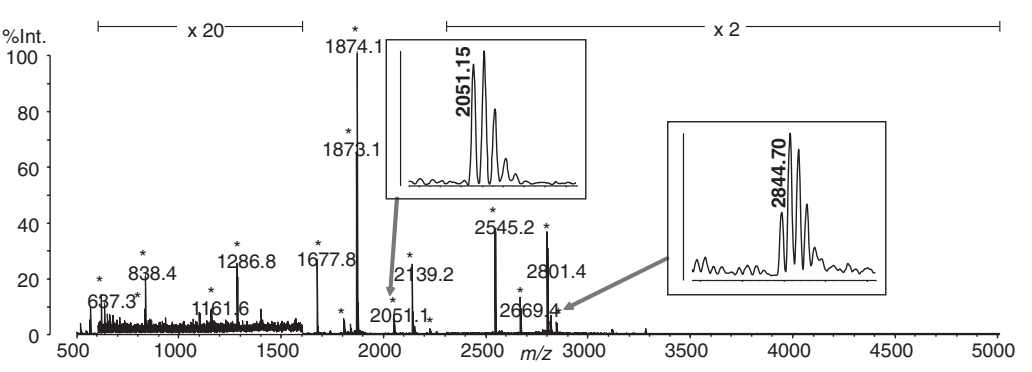

D) $A \beta-P E G_{36}-F c$
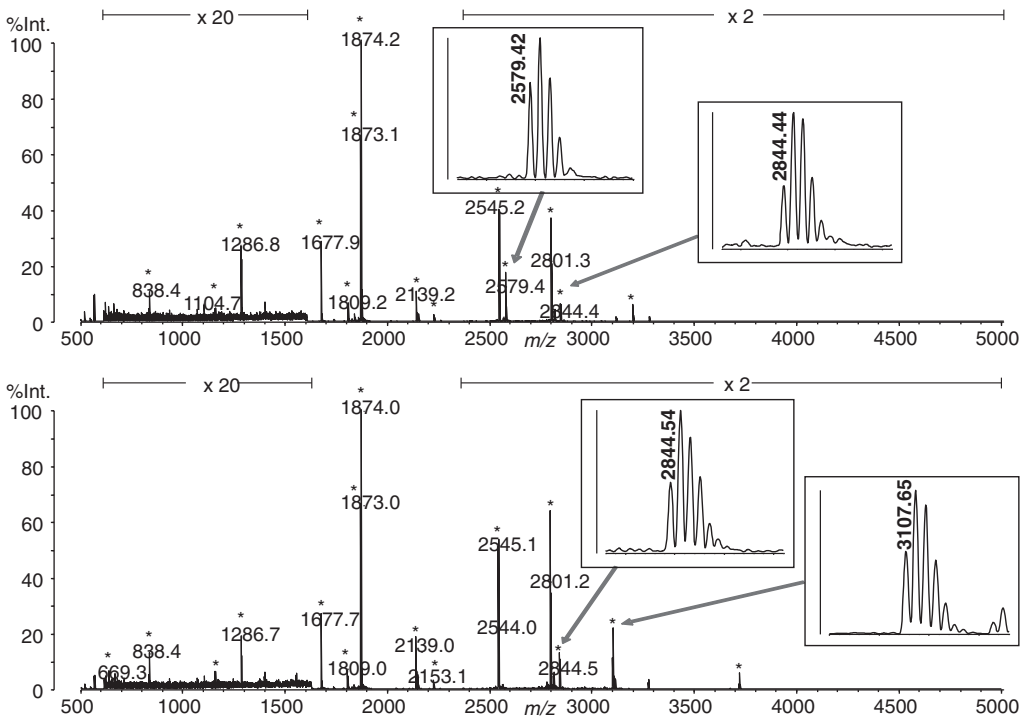

E)

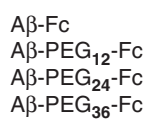

$A \beta$

Fc6

DAEFR / HDSGYEVHHQ … . DK / THT CPPCPAPELLGGPSVFLFPPKPK / $\cdots$

DAEFR / HDSGYEVHHQ- $\mathrm{PEG}_{12}$-DK / THT CPPCPAPELLGGPSVFLFPPKPK / $\ldots$

DAEFR / HDSGYEVHHQ-PEG ${ }_{24}$-DK / THT CPPCPAPELLGGPSVFLFPPKPK / $\ldots$

DAEFR / HDSGYEVHHQ- PEG $_{36}$-DK / THT CPPCPAPELLGGPSVFLFPPKPK / $\ldots$

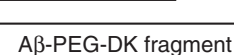

THT-Fc6 fragment

F)

\begin{tabular}{|l|c|c|}
\hline$m / z$ value & A $\beta$-PEGx-DK fragment & THT-Fc6 fragment \\
\hline$A \beta-F c$ & 1451.63 & 2844.46 \\
\hline$A \beta-P E G_{12}-F c$ & 2050.98 & 2844.46 \\
\hline$A \beta-P E G_{24}-F c$ & 2579.30 & 2844.46 \\
\hline$A \beta-P E G_{36}-F c$ & 3107.61 & 2844.46 \\
\hline
\end{tabular}

Fig. 3. MS spectra of tryptic peptides of the four $\mathrm{A} \beta-\mathrm{PEG}_{\mathrm{x}}-\mathrm{Fc}$ fusion proteins, which are as follows: (A) A $\beta$-Fc; (B) $\mathrm{A} \beta-\mathrm{PEG} 12-\mathrm{Fc} ;(\mathrm{C})$ $\mathrm{A} \beta-\mathrm{PEG}_{24}-\mathrm{Fc}$; (D) A $\beta-\mathrm{PEG}_{36}-\mathrm{Fc}$. The asterisks $\left(^{*}\right)$ denote the peaks from the fusion proteins. The insets show the $\mathrm{A} \beta-\mathrm{PEG}_{\mathrm{x}}-\mathrm{DK}$ and THT-Fc6 tryptic fragments. (E) Predicted sequence of the ligation site showing the site of trysin cleavage. (F) Theoretical $m / z$ values of the tryptic fragments derived from the ligation site. 

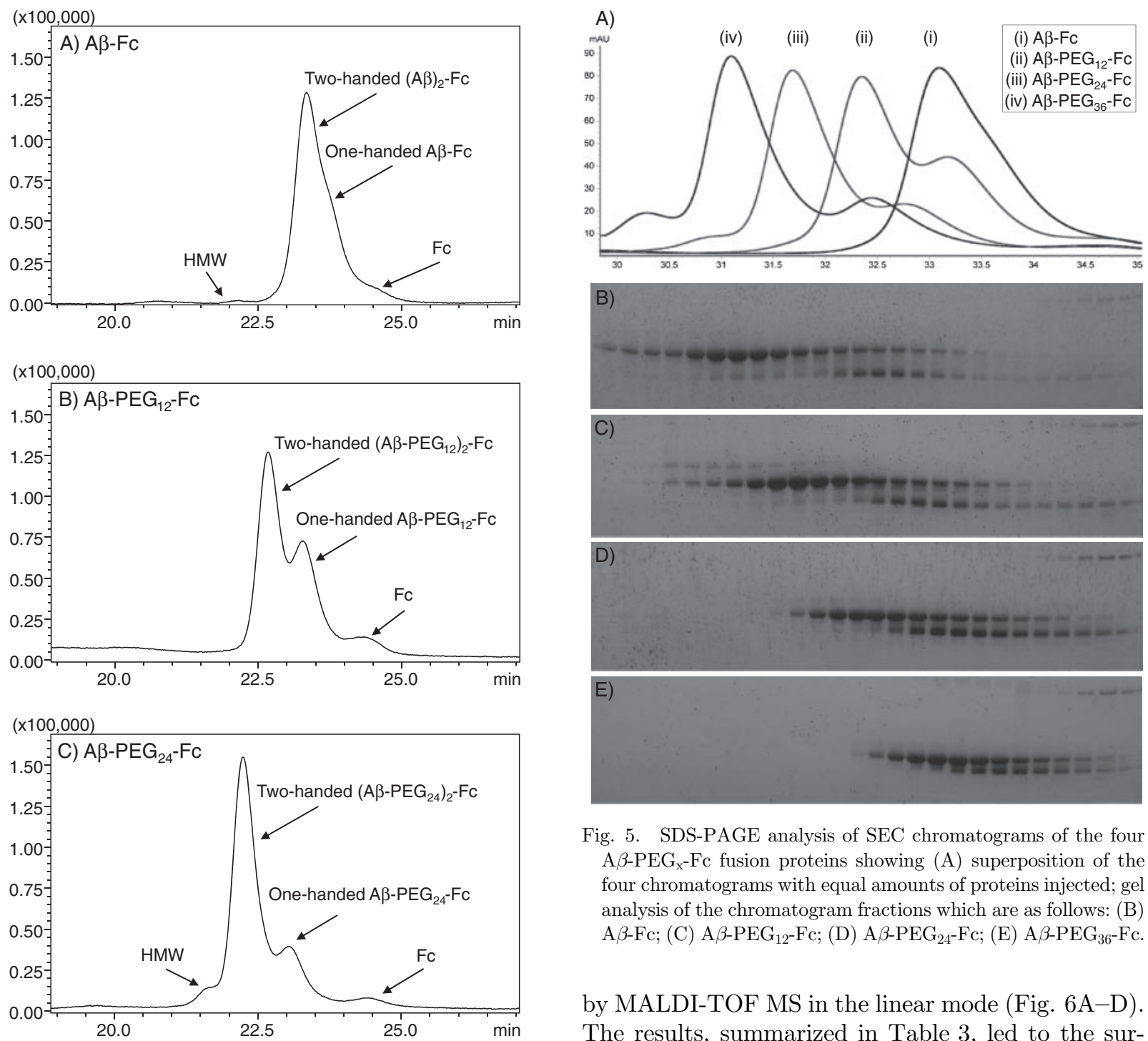

Fig. 5. SDS-PAGE analysis of SEC chromatograms of the four $\mathrm{A} \beta-\mathrm{PEG}_{\mathrm{X}}-\mathrm{Fc}$ fusion proteins showing (A) superposition of the four chromatograms with equal amounts of proteins injected; gel analysis of the chromatogram fractions which are as follows: (B) $\mathrm{A} \beta-\mathrm{Fc} ;(\mathrm{C}) \mathrm{A} \beta-\mathrm{PEG}_{12}-\mathrm{Fc}$; (D) A $\beta-\mathrm{PEG}_{24}-\mathrm{Fc}$; (E) A $\beta-\mathrm{PEG}_{36}-\mathrm{Fc}$.

by MALDI-TOF MS in the linear mode (Fig. 6A-D). The results, summarized in Table 3, led to the surprising finding that the difference in molecular weight $(\times 100,000)$

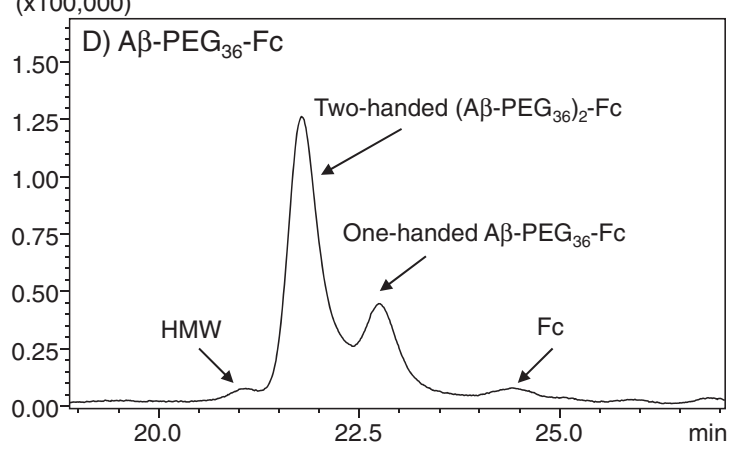

Fig. 4. SEC of the four $\mathrm{A} \beta-\mathrm{PEG}_{\mathrm{X}}-\mathrm{Fc}$ fusion proteins, as follows: (A) $\mathrm{A} \beta-\mathrm{Fc}$; (B) $\mathrm{A} \beta-\mathrm{PEG}_{12}-\mathrm{Fc} ;(\mathrm{C}) \mathrm{A} \beta-\mathrm{PEG}_{24}-\mathrm{Fc}$; (D) $\mathrm{A} \beta-\mathrm{PEG}_{36^{-}}$ Fc. The arrows show the positions of the principal peaks corresponding to the $\mathrm{Fc}$ dimer with two $\mathrm{A} \beta_{1-15}$ hands, one $\mathrm{A} \beta_{1-15}$ hand, and no $\mathrm{A} \beta_{1-15}$ hands. HMW, higher molecular weight species. $(\Delta \mathrm{MW})$ between the $\mathrm{A} \beta-\mathrm{PEG}_{\mathrm{x}}-\mathrm{Fc}$ reaction product and the apparently "unreacted" Fc6 was consistently approximately 238 daltons greater than expected. For all four $\mathrm{A} \beta$ symmetroadhesins the observed $\Delta \mathrm{MW}$ corresponds to the molecular weight of the fragment $\mathrm{A} \beta$-PEG $\mathrm{X}_{\mathrm{X}}$-DKT. These results strongly suggest that the smaller chain present in the one-handed heterodimer is not the expected unreacted Fc6 monomer chain but instead represents the $\mathrm{A} \beta-\mathrm{PEG}_{\mathrm{x}}-\mathrm{Fc}$ reaction product which has been subsequently cleaved within the upper hinge region (DKTHT) between the ${ }^{223} \mathrm{Thr}$ and ${ }^{224}$ His residues (Fig. 7).

Surface plasmon resonance studies. As the major reaction product obtained for all four $A \beta$ symmetroadhesins was the two-handed homodimer, we investigated whether such preparations had the 


\section{A) $\mathrm{A} \beta-\mathrm{FC}$}

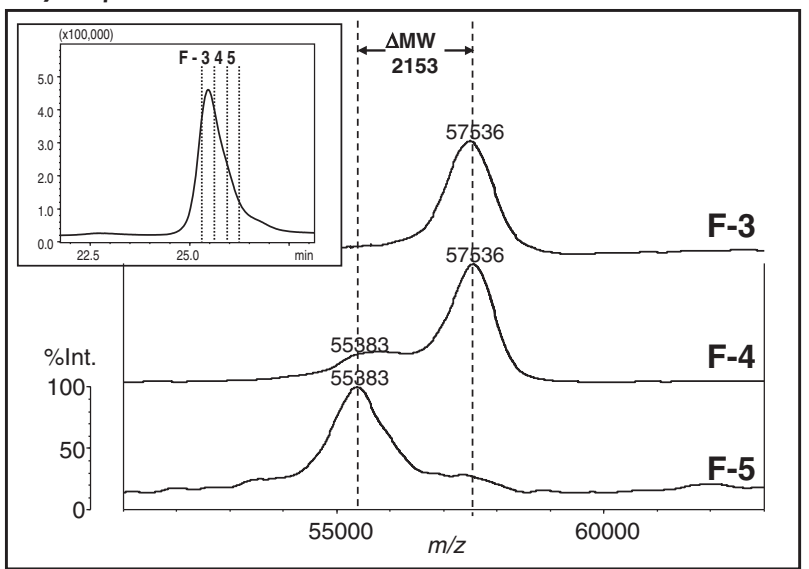

B) $A \beta-P E G_{12}-F c$

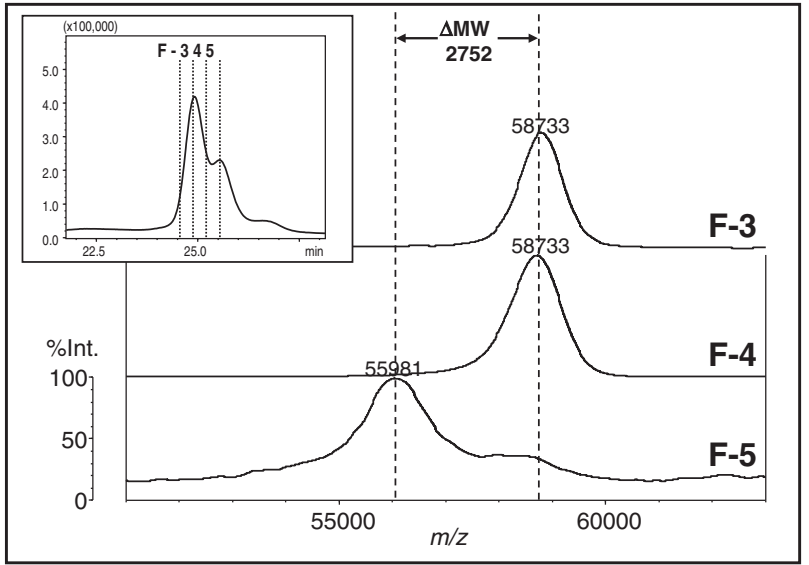

C) $\mathrm{A} \beta-\mathrm{PEG}_{24}-\mathrm{FC}$

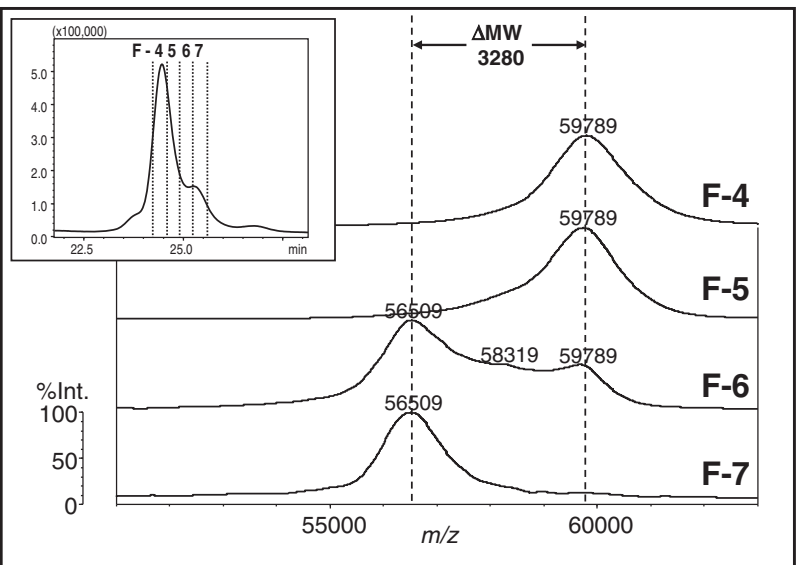

D) $\mathrm{A} \beta-\mathrm{PEG} \mathrm{G}_{36} \mathrm{-FC}$

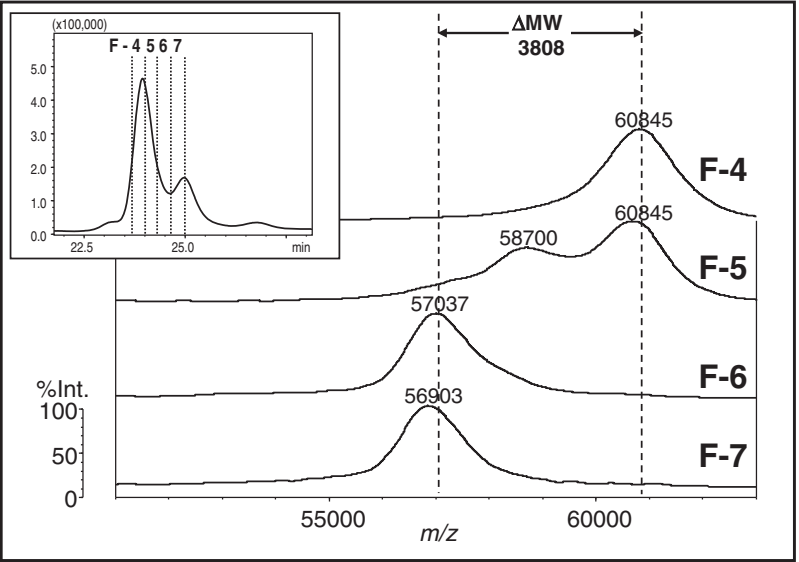

Fig. 6. MS spectra of the two principal peaks of SEC chromatograms of the four A $\beta$-PEG $\mathrm{x}_{\mathrm{x}} \mathrm{Fc}$ fusion proteins, as follows: (A) A $\beta$-Fc; (B) $\mathrm{A} \beta-\mathrm{PEG}_{12}-\mathrm{Fc}$; (C) $\mathrm{A} \beta-\mathrm{PEG}_{24}-\mathrm{Fc}$; (D) $\mathrm{A} \beta-\mathrm{PEG}_{36}-\mathrm{Fc}$. The insets show the fractions selected from the individual chromatograms for MS analysis.

Table 3. $\mathrm{A} \beta-\mathrm{PEG}_{\mathrm{x}}-\mathrm{Fc}$ symmetroadhesin product sizes determined by MALDI-TOF MS analysis of SEC fractions

\begin{tabular}{|c|c|c|c|c|c|}
\hline \multirow{2}{*}{ Reaction } & \multicolumn{2}{|c|}{ MW (observed) ${ }^{1}$} & \multirow{2}{*}{$\Delta \mathrm{MW}^{2}$} & \multicolumn{2}{|c|}{ MW (theoretical) } \\
\hline & Two-Handed & One-Handed & & A $\beta$-PEGx-DKTHT & $\mathrm{A} \beta$-PEGx-DKT \\
\hline $\mathrm{A} \beta-\mathrm{Fc}$ & 57,536 & 55,383 & 2,153 & 2,390 & 2,152 \\
\hline $\mathrm{A} \beta-\mathrm{PEG}_{12}-\mathrm{Fc}$ & 58,733 & 55,981 & 2,752 & 2,989 & 2,751 \\
\hline $\mathrm{A} \beta-\mathrm{PEG}_{24}-\mathrm{Fc}$ & 59,789 & 56,509 & 3,280 & 3,518 & 3,280 \\
\hline $\mathrm{A} \beta-\mathrm{PEG}_{36}-\mathrm{Fc}$ & 60,845 & 57,037 & 3,808 & 4,046 & 3,808 \\
\hline
\end{tabular}

${ }^{1}$ MW for the two-handed and one-handed products in each of the four (4) reactions shown in Figs. 4A-D.

${ }^{2} \mathrm{MW}$ difference between the two-handed and one-handed products in each reaction.

MW, molecular weight.

ability to bind dimeric targets as two-handed molecules. This analysis was carried out using a monoclonal antibody capable of interacting with both of the $\mathrm{A} \beta$ sequences that were incorporated into the two-handed symmetroadhesin homodimers. The DAEFRHDSGYEVHHQ sequence is well suited for this purpose as it contains the principal epitope (EFRHD) recognized by a number of monoclonal antibodies that are reactive with human $\mathrm{A} \beta(1-42)$ fibrils including $6 \mathrm{E} 10,{ }^{18)} \mathrm{PFA} 1$ and PFA2 ${ }^{19)} \mathrm{WO}-$ $2,{ }^{20)}$ and $12 \mathrm{~A} 11,10 \mathrm{D} 5$ and $12 \mathrm{~B} 4 .^{21)}$ Accordingly, we characterized the binding of our $\mathrm{A} \beta$ symmetroadhe- 

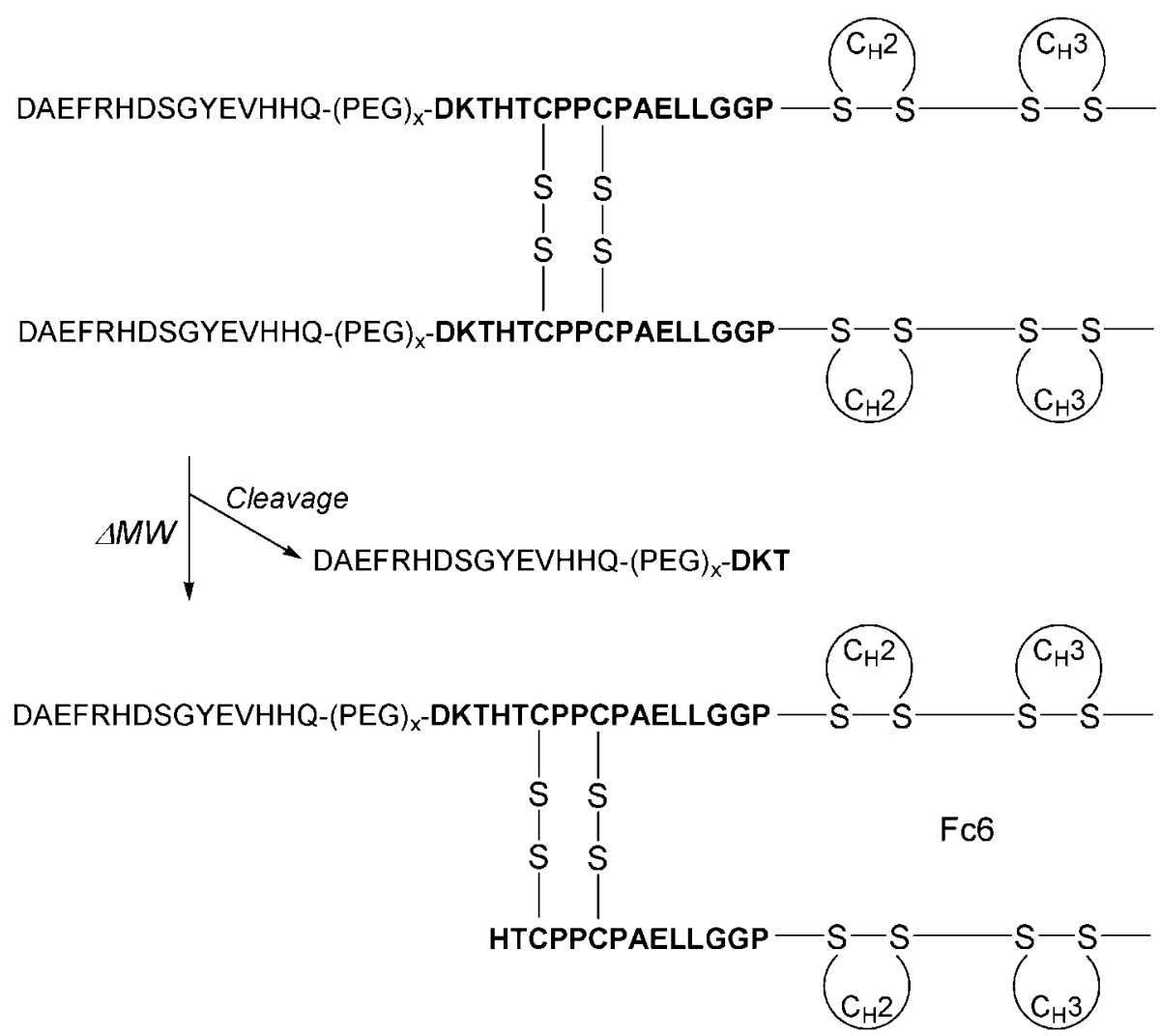

Fig. 7. Schematic diagram of the structures of the two-handed and one-handed $A \beta-P E G_{x}-F c$ fusion proteins showing a model for the generation of a one-handed fusion protein heterodimer by cleavage of the two-handed fusion protein homodimer. The sequences of the IgG1 hinge region are shown in boldface.

sins to one of these antibodies (6E10) using surface plasmon resonance (SPR). We compared the binding of $\mathrm{A} \beta$ peptides containing the DAEFRHDSGYEVHHQ sequence which were expected to bind 6 E10 in a one-handed manner. Figure 8 shows the results obtained when $6 \mathrm{E} 10$ was immobilized on the surface of the SPR chip. Specific binding was observed with all four $\mathrm{A} \beta$ symmetroadhesins (Fig. 8A-D) and with two peptides, pen- $\mathrm{A} \beta$ and $\mathrm{A} \beta$-pra (Table 1 ), that contained the 15 amino acid $\mathrm{A} \beta$ sequence (Fig. $8 \mathrm{E}-\mathrm{F}$ ). No binding was observed with Fc6 or the DKTHT-Fc6 symmetroadhesin (Fig. 2, lane 2) confirming that binding was specific for the $\mathrm{A} \beta$ sequence.

The binding of $6 \mathrm{E} 10$ by the $\mathrm{A} \beta$ symmetroadhesins was qualitatively and quantitatively different from that of the $\mathrm{A} \beta$ peptides (Fig. 8). The kinetic binding curves for both of the peptides gave a good fit with a 1:1 Langmuir model $\left(\mathrm{Chi}^{2}<0.1\right)$, consistent with one-handed binding. In contrast, the four $\mathrm{A} \beta$ symmetroadhesins did not give a good fit with the 1:1 Langmuir model $\left(\mathrm{Chi}^{2}>10\right)$, indicating two classes of binding sites. As summarized in Table 4, a good fit was obtained for the four $\mathrm{A} \beta$ symmetroadhesins employing a two-exponential model $\left(\mathrm{Chi}^{2}<1.1\right)$. The single affinity site exhibited by the pen-A $\beta$ $(17 \mathrm{nM})$ and $\mathrm{A} \beta$-pra $(20 \mathrm{nM})$ peptides was similar to the low affinity sites observed for the $\mathrm{A} \beta-\mathrm{Fc}$ $(140 \mathrm{nM}), \quad \mathrm{A} \beta-\mathrm{PEG}_{12}-\mathrm{Fc} \quad(93 \mathrm{nM}), \quad \mathrm{A} \beta-\mathrm{PEG}_{24}-\mathrm{Fc}$ $(70 \mathrm{nM})$ and $\mathrm{A} \beta-\mathrm{PEG}_{36}-\mathrm{Fc}(62 \mathrm{nM})$ symmetroadhesins (Table 4). This low affinity site was consistent with a one-handed binding mechanism by a fraction of the symmetroadhesin population. In addition, the $\mathrm{A} \beta$-Fc, $\mathrm{A} \beta-\mathrm{PEG}_{12}-\mathrm{Fc}, \mathrm{A} \beta-\mathrm{PEG}_{24}-\mathrm{Fc}$ and $\mathrm{A} \beta-\mathrm{PEG}_{36^{-}}$ Fc symmetroadhesins all displayed a much higher affinity site that was greater by two to five orders of magnitude over the corresponding low affinity sites, providing strong evidence for the existence of twohanded binding of $6 \mathrm{E} 10$ by a significant fraction (19$27 \%$ ) of the $\mathrm{A} \beta$ symmetroadhesins (Table 4).

\section{Discussion}

Proteins prefer to form compact globular or fibrous structures, minimizing their exposure to 


\section{A) DAEFRHDSGYEVHHQ-DKTHT-Fc6}

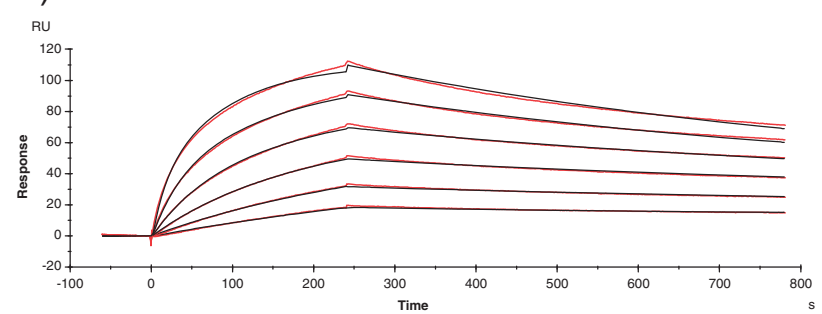

B) DAEFRHDSGYEVHHQ-PEG 12 -DKTHT-Fc6

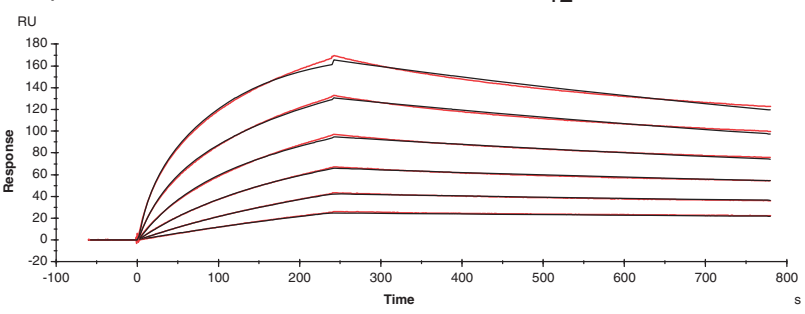

E) pen-DAEFRHDSGYEVHHQ

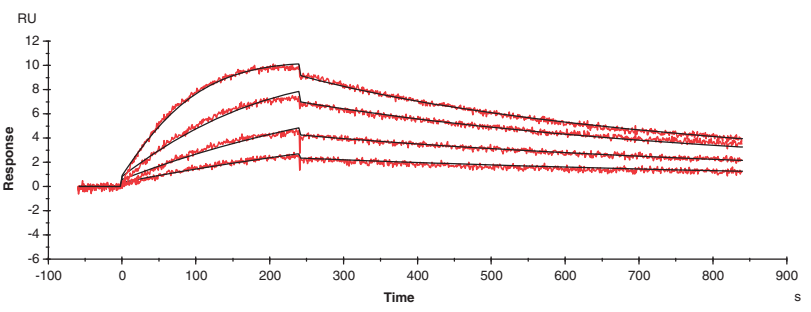

C) DAEFRHDSGYEVHHQ-PEG 24 -DKTHT-Fc6

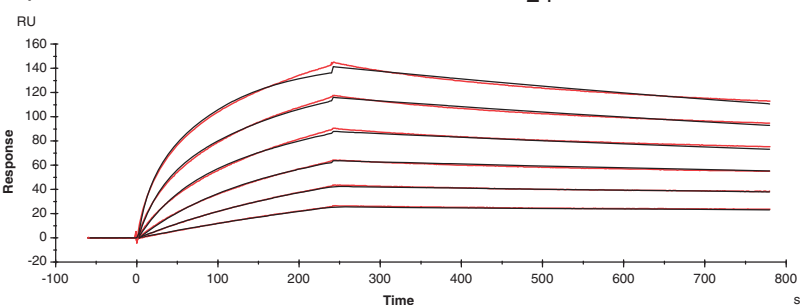

D) DAEFRHDSGYEVHHQ-PEG ${ }_{36}$-DKTHT-Fc6

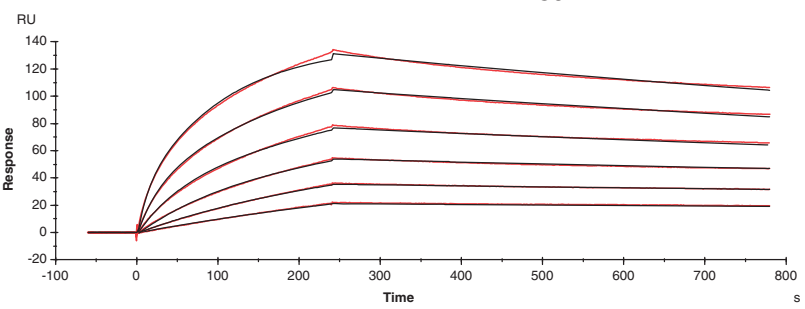

F) DAEFRHDSGYEVHHQ-pra

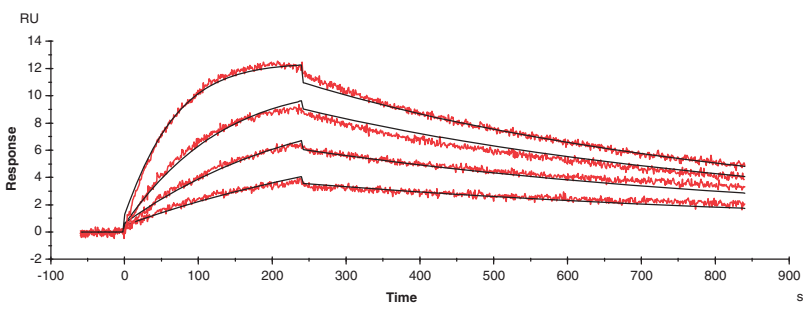

Fig. 8. Surface plasmon resonance (SPR) analysis of binding of anti-A $\beta$ mAb (6E10) binding by the four $\mathrm{A} \beta-\mathrm{PEG}$-Fc fusion proteins and two $\mathrm{A} \beta_{1-15}$ peptides, which are as follows: (A) A $\beta-\mathrm{Fc}$; (B) $\mathrm{A} \beta-\mathrm{PEG}_{12}-\mathrm{Fc}$; (C) $\mathrm{A} \beta-\mathrm{PEG}_{24}-\mathrm{Fc}$; (D) $\mathrm{A} \beta-\mathrm{PEG} 36-\mathrm{Fc}$; (E) pen-(A $\left.\beta_{1-15}\right)$, (F) $\left(\mathrm{A} \beta_{1-15}\right)$-pra. The actual binding curve traces are shown in red; the binding curve fits are shown in black.

Table 4. Kinetic results for Mab-6E10 binding measured by surface plasmon resonance

\begin{tabular}{|c|c|c|c|c|c|c|c|c|c|}
\hline A $\beta$ Symmetroadhesin & $\mathrm{ka} 2(1 / \mathrm{Ms})$ & $\operatorname{kd} 2(1 / \mathrm{s})$ & $\mathrm{KD} 2(\mathrm{M})$ & $\mathrm{Rmax} 2$ & $\mathrm{ka1}(1 / \mathrm{Ms})$ & $\operatorname{kd} 1(1 / \mathrm{s})$ & $\mathrm{KD} 1(\mathrm{M})$ & $R \max 1$ & $\mathrm{Chi}^{2}$ \\
\hline $\begin{array}{l}\text { DAEFRHDSGYEVHHQ- } \\
\text { DKTHT-Fc6 }\end{array}$ & $6.119 \mathrm{E}+04$ & $4.742 \mathrm{E}-05$ & $7.749 \mathrm{E}-10$ & 34.9 & $1.010 \mathrm{E}+04$ & $1.414 \mathrm{E}-03$ & $1.401 \mathrm{E}-07$ & 91.5 & 0.96 \\
\hline $\begin{array}{l}\text { DAEFRHDSGYEVHHQ-PEG }{ }_{12^{-}} \\
\text {DKTHT-Fc6 }\end{array}$ & $7.858 \mathrm{E}+04$ & $4.127 \mathrm{E}-08$ & $5.251 \mathrm{E}-13$ & 37.4 & $8.865 \mathrm{E}+03$ & $8.290 \mathrm{E}-04$ & $9.350 \mathrm{E}-08$ & 155.5 & 0.98 \\
\hline $\begin{array}{l}\text { DAEFRHDSGYEVHHQ-PEG }{ }_{24^{-}} \\
\text {DKTHT-Fc6 }\end{array}$ & $7.965 \mathrm{E}+04$ & $4.747 \mathrm{E}-07$ & $5.960 \mathrm{E}-12$ & 40 & $9.592 \mathrm{E}+03$ & $6.728 \mathrm{E}-04$ & $7.014 \mathrm{E}-08$ & 119 & 1.1 \\
\hline $\begin{array}{l}\text { DAEFRHDSGYEVHHQ-PEG }{ }_{36^{-}} \\
\text {DKTHT-Fc6 }\end{array}$ & $8.347 \mathrm{E}+04$ & $4.429 \mathrm{E}-06$ & $5.306 \mathrm{E}-11$ & 29.7 & $9.080 \mathrm{E}+03$ & $5.695 \mathrm{E}-04$ & $6.272 \mathrm{E}-08$ & 119.9 & 0.72 \\
\hline $\mathrm{A} \beta$ Peptide & & & & & $\mathrm{ka1}(1 / \mathrm{Ms})$ & $\mathrm{kd} 1(1 / \mathrm{s})$ & $\mathrm{KD} 1(\mathrm{M})$ & $R \max 1$ & $\mathrm{Chi}^{2}$ \\
\hline $\begin{array}{l}\text { pentynoyl-DAEFRHDSGYEVHHQ- } \\
\mathrm{NH}_{2}\end{array}$ & & & & & $1.055 \mathrm{E}+05$ & $2.114 \mathrm{E}-03$ & $2.003 \mathrm{E}-08$ & 10.4 & 0.039 \\
\hline $\begin{array}{l}\text { DAEFRHDSGYEVHHQ- } \\
\text { propargylglycine-NH }{ }_{2}\end{array}$ & & & & & $9.531 \mathrm{E}+04$ & $1.601 \mathrm{E}-03$ & $1.679 \mathrm{E}-08$ & 12.2 & 0.075 \\
\hline
\end{tabular}


solvent. This tendency is inherent both in the polypeptide backbone with its propensity for hydrogen-bonded secondary structure, and in side chain interactions that promote tertiary folding. Thus, previous efforts to introduce "flexibility" into antibodies using peptides have been largely inadequate. For example, it is common to employ combinations of an amino acid that favors solvent interactions (e.g., serine) with one that breaks up helical structure (e.g., glycine). While this approach is useful in making fusion proteins such as single-chain antibody fragments $(\mathrm{scFv})$, the resulting structures are quite compact with no evidence of extendibility (for example, see ref. 20). Furthermore, such sequences are likely to create additional problems due to the intrinsic immunogenicity and proteolytic susceptibility.

We pursued a novel strategy that introduces nonprotein chains into the hinge region by chemical semisynthesis. Our results demonstrate quantitative yields of antibody-like molecules with nonprotein hinges connecting two $\mathrm{A} \beta_{1-15}$ peptides with the $\mathrm{Fc}$ dimer. These molecules form two-handed native dimers that display high affinity for an anti- $\mathrm{A} \beta$ monoclonal antibody. Our A $\beta-\mathrm{PEG}_{\mathrm{x}}-\mathrm{Fc}$ dimers with a nonprotein hinge have an affinity that is two to five orders of magnitude greater than the cognate peptide and appear to bind much better than the $\mathrm{A} \beta-\mathrm{Fc}$ dimer. A full interpretation of these results awaits the determination of the three-dimensional structure for the $\mathrm{A} \beta_{1-15}$ peptide, which contains the immunodominant epitope of Alzheimer's A $\beta(1-42)$ fibrils. Although the exact configuration of this epitope (DAEFRHDS) in complex with Fab fragments has been resolved in x-ray structures, ${ }^{19), 21)}$ the same region appears disordered in $3 \mathrm{D}$ structures of A $\beta(1-42)$ fibrils obtained by quenched hydrogen/ deuterium-exchange NMR studies. ${ }^{27)}$

Analysis by SDS-polyacrylamide gel electrophoresis indicates that the formation of the desired $\mathrm{A} \beta$ $\mathrm{PEG}_{\mathrm{x}}-\mathrm{Fc}$ fusion protein exceeds $90 \%$. In addition, MS analysis of the one-handed reaction products purified by SEC indicates that they contain two reacted Fc polypeptides (Fig. 7), one of which is full-length while the other has been hydrolyzed at the T/HT sequence, a major site of proteolysis (e.g., papain). ${ }^{9)}$ Thus, the overall efficiency of the native chemical ligation step, excluding the subsequent cleavage, may be much closer to $100 \%$. The native ligation conditions also appear to be fully compatible with the native structure and biological activity of the Fc dimer, while adding some of the properties of nonprotein polymers. Our results show that the addition of discrete oxyethylene oligomers not only improves binding, but also appears to have a significant effect on the hydrodynamic radius of the Fc protein as evidenced by size-exclusion chromatography of the $\mathrm{A} \beta-\mathrm{PEG}_{12}-\mathrm{Fc}, \mathrm{A} \beta-\mathrm{PEG}_{24}-\mathrm{Fc}$ and $\mathrm{A} \beta$ $\mathrm{PEG}_{36}-\mathrm{Fc}$ molecules when compared with the $\mathrm{A} \beta-\mathrm{Fc}$ molecule.

MALDI-TOF MS appears to be ideally suited for the characterization of our novel proteinnonprotein-protein molecules. The mass contributed by the hybrid structures can be efficiently characterized not only in tryptic digests, but also in the two-handed and one-handed native Fc dimers. Ionization and desorption appear to be mediated by the adjacent protein sequences in our proteinnonprotein hybrid molecules, suggesting the application of this approach to a broad range of chemically distinct polymer chains.

In conclusion, we have described here a significant step towards our goal of the complete chemical semisynthesis of antibodies with nonprotein hinges that incorporate large binding domains such as the Fab region itself or receptor extracellular domains. Additional progress will depend upon the identification of other protein ligation reactions that can be combined with native chemical ligation, are similarly compatible with the native structure and function of the cognate proteins, and which can proceed efficiently at the micromolar concentrations that are attainable with such native proteins in solution. The antibody-like molecules we envision have enormous potential as therapeutic candidates with improved binding affinity for their disease targets.

\section{Acknowledgements}

This research is granted by the Japan Society for the Promotion of Science (JSPS) through the "Funding Program for World-Leading Innovative R\&D on Science and Technology (FIRST Program)," initiated by the Council for Science and Technology Policy (CSTP).

\section{References}

1) Pauling, L. (1940) A theory of the structure and process of formation of antibodies. J. Am. Chem. Soc. 62, 2643-2657.

2) Porter, R.R. (1958) Separation and isolation of fractions of rabbit gamma-globulin containing the antibody and antigenic combining sites. Nature 182, 670-671.

3) Edelman, G.M., Cunningham, B.A., Gall, W.E., Gottlieb, P.D., Rutishauser, U. and Waxdal, M.J. (1969) The covalent structure of an entire $\gamma \mathrm{G}$ 
immunoglobulin molecule. Proc. Natl. Acad. Sci. U.S.A. 63, 78-85.

4) Feinstein, A. and Rowe, A.J. (1965) Molecular mechanism of formation of an antigen-antibody complex. Nature 205, 147-149.

5) Valentine, R.C. and Green, N.M. (1967) Electron microscopy of an antibody hapten complex. J. Mol. Biol. 27, 615-617.

6) Saphire, E.O., Stanfield, R.L., Crispin, M.D., Parren, P.W., Rudd, P.M., Dwek, R.A., Burton, D.R. and Wilson, I.A. (2002) Contrasting IgG structures reveal extreme asymmetry and flexibility. J. Mol. Biol. 319, 9-18.

7) Capon, D.J., Chamow, S.M., Mordenti, J., Marsters, S.A., Gregory, T., Mitsuya, H., Byrn, R.A., Lucas, C., Wurm, F.M., Groopman, J.E., Broder, S. and Smith, D.H. (1989) Designing CD4 immunoadhesins for AIDS therapy. Nature 337, 525-531.

8) Byrn, R.A., Mordenti, J., Lucas, C., Smith, D., Marsters, S.A., Johnson, J.S., Cossum, P., Chamow, S.M., Wurm, F.M., Gregory, T., Groopman, J.E. and Capon, D.J. (1990) Biological properties of a CD4 immunoadhesin. Nature $\mathbf{3 4 4}$ 667-670.

9) Chamow, S.M., Peers, D.H., Byrn, R.A., Mulkerrin, M.G., Harris, R.J., Wang, W.C., Bjorkman, P.J., Capon, D.J. and Ashkenazi, A. (1990) Enzymatic cleavage of a CD4 immunoadhesin generates crystallizable, biologically active Fd-like fragments. Biochemistry 29, 9885-9891.

10) Ward, R.H., Capon, D.J., Jett, C.M., Murthy, K.K., Mordenti, J., Lucas, C., Frie, S.W., Prince, A.M., Green, J.D. and Eichberg, J.W. (1991) Prevention of HIV-1 IIIB infection in chimpanzees by CD4 immunoadhesin. Nature 352, 434-436.

11) Watson, S.R., Imai, Y., Fennie, C., Geoffroy, J.S., Rosen, S.D. and Lasky, L.A. (1990) A homing receptor-IgG chimera as a probe for adhesive ligands of lymph node high endothelial venules. J. Cell Biol. 110, 2221-2229.

12) Watson, S.R., Fennie, C. and Lasky, L.A. (1991) Neutrophil influx into an inflammatory site inhibited by a soluble homing receptor-IgG chimaera. Nature 349, 164-167.

13) Ashkenazi, A., Marsters, S.A., Capon, D.J., Chamow, S.M., Figari, I.S., Pennica, D., Goeddel, D.V., Palladino, M.A. and Smith, D.H. (1991) Protection against endotoxic shock by a tumor necrosis factor receptor immunoadhesin. Proc. Natl. Acad. Sci. U.S.A. 88, 10535-10539.

14) Ashkenazi, A., Capon, D.J. and Ward, R.H. (1993) Immunoadhesins. Int. Rev. Immunol. 10, 219-227.

15) Reichert, J.M. (2011) Antibody-based therapeutics to watch in 2011. MAbs 3, 76-99.

16) Flory, P.J. (1969) Statistical Mechanics of Chain Molecules. Interscience Publishers, New York.

17) Dawson, P.E. and Kent, S.B. (2000) Synthesis of native proteins by chemical ligation. Annu. Rev. Biochem. 69, 923-960.

18) Pirttila, T., Kim, K.S., Mehta, P.D., Frey, H. and
Wisniewski, H.M. (1994) Soluble amyloid $\beta$ protein in the cerebrospinal fluid from patients with Alzheimer's disease, vascular dementia and controls. J. Neurol. Sci. 127, 90-95.

19) Gardberg, A.S., Dice, L.T., Ou, S., Rich, R.L., Helmbrecht, E., Ko, J., Wetzel, R., Myszka, D.G., Patterson, P.H. and Dealwis, C. (2007) Molecular basis for passive immunotherapy of Alzheimer's disease. Proc. Natl. Acad. Sci. U.S.A. 104, 15659-15664.

20) Robert, R., Dolezal, O., Waddington, L., Hattarki, M.K., Cappai, R., Masters, C.L., Hudson, P.J. and Wark, K.L. (2009) Engineered antibody intervention strategies for Alzheimer's disease and related dementias by targeting amyloid and toxic oligomers. Protein Eng. Des. Sel. 22, 199-208.

21) Basi, G.S., Feinberg, H., Oshidari, F., Anderson, J., Barbour, R., Baker, J., Comery, T.A., Diep, L., Gill, D., Johnson-Wood, K., Goel, A., Grantcharova, K., Lee, M., Li, J., Partridge, A., Griswold-Prenner, I., Piot, N., Walker, D., Widom, A., Pangalos, M.N., Seubert, P., Jacobsen, J.S., Schenk, D. and Weis, W.I. (2010) Structural correlates of antibodies associated with acute reversal of $\mathrm{A} \beta$-related behavioral deficits in a mouse model of Alzheimer disease. J. Biol. Chem. 285, 3417-3427.

22) Tanaka, K., Waki, H., Ido, Y., Akita, S., Yoshida, Y. and Yoshida, T. (1988) Protein and polymer analyses up to $m / z 100,000$ by laser ionization time-of-flight mass spectrometry. Rapid Commun. Mass Spectrom. 2, 151-153.

23) Koy, C., Mikkat, S., Raptakis, E., Sutton, C., Resch, M., Tanaka, K. and Glocker, M.O. (2003) Matrixassisted laser desorption/ionization- quadrupole ion trap-time of flight mass spectrometry sequencing resolves structures of unidentified peptides obtained by in-gel tryptic digestion of haptoglobin derivatives from human plasma proteomes. Proteomics 3, 851-858.

24) Kabat, E.A., Wu, T.T., Perry, H.M., Gottesman, K.S. and Foeller, C. (1991) Sequences of Proteins of Immunological Interest, 5th ed. National Institutes of Health, Bethesda, MD.

25) Rajendra, Y., Kiseljak, D., Baldi, L., Hacker, D.L. and Wurm, F.M. (2011) A simple high-yielding process for transient gene expression in $\mathrm{CHO}$ cells. J. Biotechnol. 153, 22-26.

26) Johnson, E.C. and Kent, S.B. (2006) Insights into the mechanism and catalysis of the native chemical ligation reaction. J. Am. Chem. Soc. 128, 66406646 .

27) Lührs, T., Ritter, C., Adrian, M., Riek-Loher, D., Bohrmann, B., Dobeli, H., Schubert, D. and Riek, R. (2005) 3D structure of Alzheimer's A $\beta(1-42)$ fibrils. Proc. Natl. Acad. Sci. U.S.A. 102, 1734217347. 